\title{
Learner Needs Analysis in an ESP Class
}

\section{Effrosyni K. Giannarou}

12, Patriarhou Fotiou St, 13121 Ilion, Greece

Email: frosgian@hotmail.com

How to cite this paper: Giannarou, E. K. (2021). Learner Needs Analysis in an ESP Class. Open Journal of Modern Linguistics, $11,174-200$.

https://doi.org/10.4236/ojml.2021.112015

Received: March 12, 2021

Accepted: April 6, 2021

Published: April 9, 2021

Copyright (c) 2021 by author(s) and Scientific Research Publishing Inc. This work is licensed under the Creative Commons Attribution International License (CC BY 4.0).

http://creativecommons.org/licenses/by/4.0/

\begin{abstract}
Foreign language teachers, like all teachers, design their courses by first investigating and paying attention to their learners' special needs. In this paper, a needs analysis survey is presented. This took place in a class of adult graduates from Greek Merchant Marine Academies. Learners are all naval engineers who participate in a postgraduate course with the purpose to upgrade their professional diploma. The course subject includes both general English and English for Specific Purposes-English related to vessel engine operation, service and maintenance. The learner needs analysis is done with the help of a questionnaire. The questionnaire consists of six parts. These examine the learner beliefs concerning the reasons for learning the English language, their language proficiency in English as well as reasons that they might have dropped out of language learning courses in the past. The questions asked are closed questions, checklists, rating scales and open questions. Results show that learners prefer learning English, because they view it as useful in their work. In fact, they need to be able to read and comprehend engine operation manuals and compose written forms required by them. Concerning teaching methods, learners are found to prefer group work activities. They also find the textbooks series studies in the Marine Academy as useful. Still, they propose teaching material modification which includes more group activities and technical vocabulary practice tasks.
\end{abstract}

\section{Keywords}

Learner Needs, Needs Analysis, Naval Engineer, Greek Merchant Marine Academy, General English, English for Specific Purposes, Engine Operation Manuals, Technical Vocabulary

\section{Introduction}

All foreign language teachers need to take into consideration their learners needs when designing a course. The aim of this paper is to evaluate a needs analysis 
questionnaire that focuses on the learning needs of a class of merchant navy engineers.

\section{Description of Teaching Context}

The teaching context is a class of twenty adult learners, aged from 25 to 50 years old. The learners are all naval engineers, graduates from Marine Academies who undertake a postgraduate course in order to enhance their occupational qualifications and upgrade their professional diploma. English is among the courses offered. The total teaching hours of the course are 70 and, according to the official curriculum, learners should practice both general English and English for Specific Purposes-terminology related to vessel engine operation, service and maintenance.

\section{Literature Review on Needs Analysis}

Concerning needs analysis, there are a number of definitions and efforts made by education stakeholders and specialists to define ways to describe learner needs.

Brindley mentions three types of needs: language proficiency needs, psychological-humanistic needs and specific purpose needs. The first concern the level of language knowledge learners need to attain. Psychological-humanistic needs refer to learner psychological state regarding the language learning process. For example, how confident they feel learning the language. Specific purpose needs refer to the linguistic items learners are required to master for vocational use (Brindley, 1986: p. 66).

According to Richards, needs analysis refers to "the procedures used to collect information about learners' needs” (Richards, 2012: p. 51) while Tudor defines needs analysis as the research of learners' conceptual and expressive agendas. According to him, learners of a language learning course form their personal "learning agenda" which includes the notions and intentions that they feel they should communicate in the target language (Tudor, 1996: pp. 76-77). The role of the teacher is to investigate into learners' agendas so as to record their needs. In fact, learners participate in this quest themselves by both expressing their intentions and by shaping their study in collaboration with the teacher.

West underlines the fact that needs analysis is effectuated for practical purposes; this means that teachers investigate into learner target situation needs in order to design their course syllabus (West, 1994: p. 1). Long, on the other hand, defines learner needs as "a prerequisite for effective course design" (Long, 2005: p. 1).

A common classification of learner needs is their distinction into objective and subjective needs. Objective needs refer to how the learners will use the language at the end of the course. This includes the language items and the use the learners will have acquired so as to be able to perform communicative roles. Objective needs relate, therefore, to the content of instruction. 
Subjective needs, on the other hand, relate to the process of learning. This refers to what the learners should do in order to acquire the target language (Ayakli, Karavas, Manolopoulou-Sergi, \& Spinthourakis, 2004: p. 96). Subjective needs include learning preferences and style, aptitude, motivation as well as the use of learning strategies.

There have been several models and techniques proposed for conducting learner needs analysis.

One well-known model designed to define learners' real world communicative needs is the Munby Model (1978). Tudor mentions nine parameters analyzed by this model: participant, purposive domain, setting, interaction, instrumentality, communicative event and communicative key (Tudor, 1996: p. 67).

An alternative model for needs analysis was put forward by Tarone and Yule in 1989. They defined four levels in which learners would need to use the language: the global level, the rhetorical level, the grammatical-rhetorical level and the grammatical level (Tudor, 1996: p. 72).

Nevertheless, the above two models have been criticized as limited since they only cater for learner's objective needs and fail to investigate learners' "conceptual" and "pragmatic" knowledge.

Several techniques have been proposed for conducting needs analysis. Among the most commonly used ones are questionnaires, pilot student and staff questionnaires, interviews, tests, case studies, authentic data collection, participatory needs analysis collection and consultation of qualified informants (Tudor, 1996: pp. 73-77; Richards, 2012: p. 63).

\section{Description and Rationale of the Questionnaire}

\subsection{Description of Questionnaire Structure}

The learner needs analysis questionnaire consists of six parts. The first and second parts included questions relating to the usefulness of English as a course as well as the reasons why someone should learn the language. The third part sought to record learners' language proficiency in English while the fourth part investigated the reasons behind learners' withdrawal from formal English learning courses in the past. Part E investigated English learning activities in which learners participated in the past and their view of them and Part F asked learners to comment on how they would prefer their English teacher to behave in class. The last part of the questionnaire, Part G, includes questions on the nature of English as a language as well as learner feelings about it.

Concerning the types of questions used, these included closed questions, checklists, rating scales as well as open questions. Closed ended questions were chosen since they are "readily analyzable, useful for assessing gradations of intensity" (Bogdan \& Biklen, 1998). For an example of a closed question, see Appendix I, where learners are asked to relate how they learned maritime English. The question has four possible answers and learners tick the appropriate one(s). 
Another structured item used to assess learner needs was checklists. Checklists, according to Richards (2012: p. 73) are a set of terms that describe different values. In many questionnaire questions (see Appendix I) learners are asked to classify various activities, experiences or tasks as "Very Useful" or "Useful" or "Not Useful" while in other cases they needed to provide answers like "Very True", "True" or "Not True" (see Appendix I). Scales are another type of question used (see Appendix I). In these learners were asked to assign values to a variety of teacher actions. For example, learners ticked "No," "A little," "Good," "Best" according to how they would like the teacher to behave during the English teaching lesson.

Open questions constituted another question type employed. These were chosen since they allow learners more freedom in expressing their ideas and feelings (BouJaoude, 2000: p. 174). Taking into account learner subjective needs as well, it is advisable to investigate how they feel about what they learn as well as the way in which they are being taught. It is also useful to give them space to express themselves; perhaps some new ideas will come up that will further aid course design and implementation. For examples of open questions used in the questionnaire under discussion see Appendix I.

\subsection{Description of Questionnaire Content}

The questionnaire includes questions that are relevant to learner interests and occupational status. Learners need to be motivated in order to study. The knowledge they come to contact with and the skills they practice need to be linked to their interests and they should also be able to see the long term value in what they learn (Beetham \& Sharpe, 2013: pp. 3-10). This is the reason why this questionnaire includes questions directly relating the English language with the occupational learning needs of maritime students. So, learners are asked why they think learning English might be useful in their job (see Appendix I).

Taking under consideration the fact that modern society puts greater demands on its members be they learners or professionals (Long, 2005: p. 1), the questionnaire elicits learners' evaluation of their previous general and maritime English learning courses as a way to foresee future difficulties and be able to draw a clearer picture of how learners perceive learning as well as of their various learning styles, interests and preferences (see Appendix I).

Herndon mentions that learners often feel that "instruction lacks personal relevance" (Herndon, 1987: p. 11). This is way questions in Part F of the questionnaire have been devised in order to examine how learners want the English course to be conducted (see Appendix I). Should the syllabus designer or teacher take into consideration learner responses in designing a course, learners will be "purposefully motivated" and they will find learning activities "meaningful" and "worthwhile" (Wlodkowski, 2011: p. 2).

\section{Presentation of Main Results}

The initial part of the questionnaire focused on analyzing learners' view of the 
necessity to learn the English language. This view is expressed in Figure 1. Ninety per cent $(90 \%)$ of the learners responded that learning English is very useful to them, ten per cent $(10 \%)$ responded that it is simply useful while nobody considered it useless.

Concerning the reasons why learners think English is important, as Figures 2-5 show, ninety per cent (95\%) of them agreed that they need English for reading engine operation manuals, ninety per cent $(90 \%)$ for ordering spare parts and supplies while eighty per cent (80\%) want to be able to communicate with foreign crew on board and seventy five (75\%) need to compose damage reports to the employer shipping company.

For further reasons why learners consider learning English as important, see Appendix II.

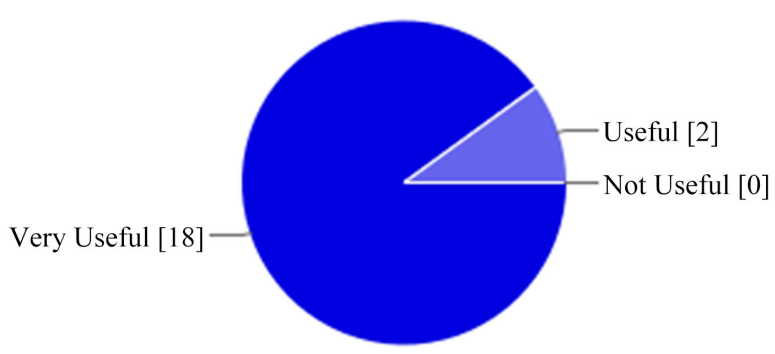

\begin{tabular}{ccc}
\hline Comment & No of responses & Percentage \% \\
\hline Very Useful & 18 & $90 \%$ \\
Useful & 12 & $10 \%$ \\
Not Useful & 0 & $0 \%$ \\
\hline
\end{tabular}

Figure 1. Do you think that English is a useful course?

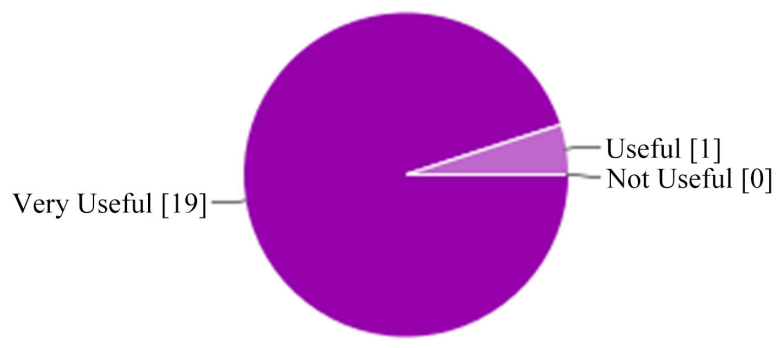

\begin{tabular}{ccc}
\hline Comment & No of responses & Percentage \% \\
\hline Very Useful & 19 & $95 \%$ \\
Useful & 1 & $5 \%$ \\
Not Useful & 0 & $0 \%$ \\
\hline
\end{tabular}

Figure 2. Reading engine operation manuals. 


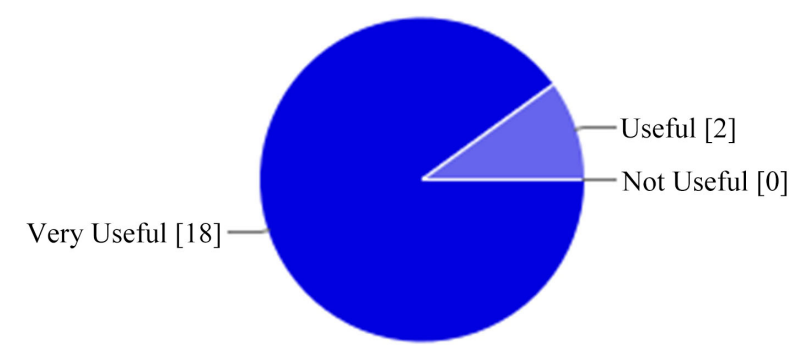

\begin{tabular}{ccc}
\hline Comment & No of responses & Percentage \% \\
\hline Very Useful & 18 & $90 \%$ \\
Useful & 2 & $10 \%$ \\
Not Useful & 0 & $0 \%$ \\
\hline
\end{tabular}

Figure 3. Ordering spare parts and supplies.

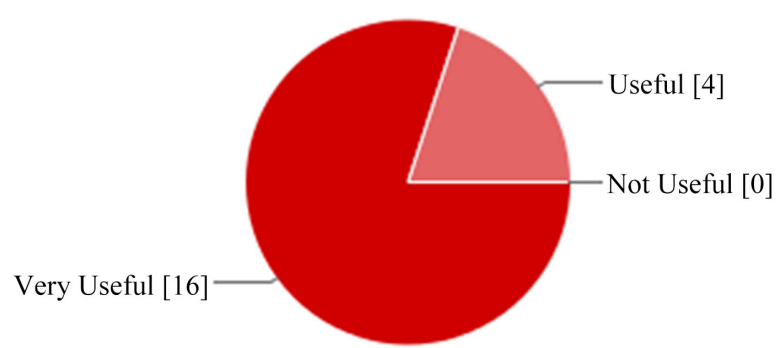

\begin{tabular}{ccc}
\hline Comment & No of responses & Percentage \% \\
\hline Very Useful & 16 & $80 \%$ \\
Useful & 4 & $20 \%$ \\
Not Useful & 0 & $0 \%$ \\
\hline
\end{tabular}

Figure 4. Collaborating with foreign crew on board.

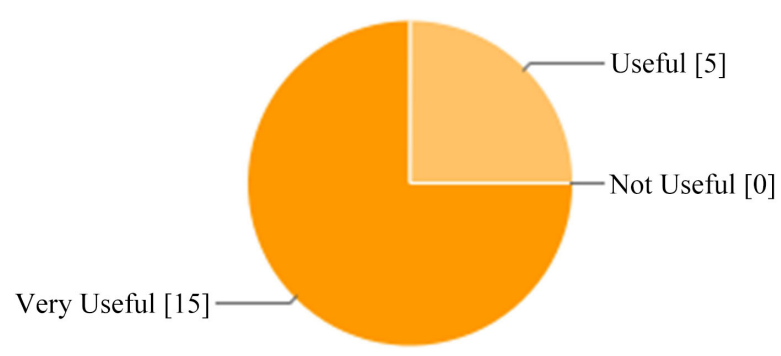

\begin{tabular}{ccc}
\hline Comment & No of responses & Percentage \% \\
\hline Very Useful & 15 & $75 \%$ \\
Useful & 5 & $25 \%$ \\
Not Useful & 0 & $0 \%$
\end{tabular}

Figure 5. Composing damage reports to the employer shipping company. 
Another issue that was investigated by the questionnaire was learners' current language ability. Both general English and maritime English knowledge were studied. According to the results shown in Figure 6 and Figure 7 below, the majority of students feel that they have an intermediate level knowledge of both general and maritime English.

A great number of learners have attended English learning courses in the past for an average of five years, from two to three hours a week. According to Figure 8 , forty per cent $(40 \%)$ found the course to be useful while fifty per cent $(50 \%)$ found it to be somewhat useful. Only ten per cent (10\%) didn't find the course useful at all.

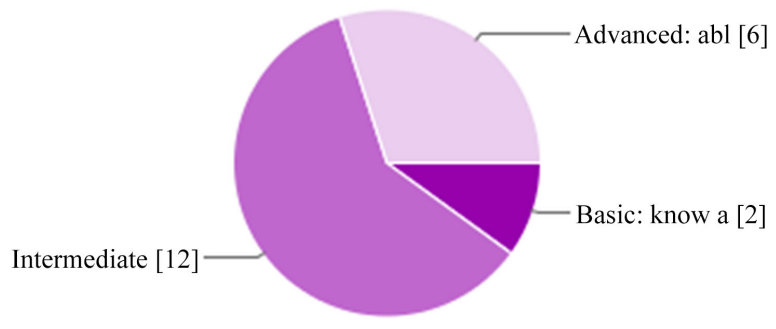

Figure 6. If you already speak English please choose your present level of language ability.

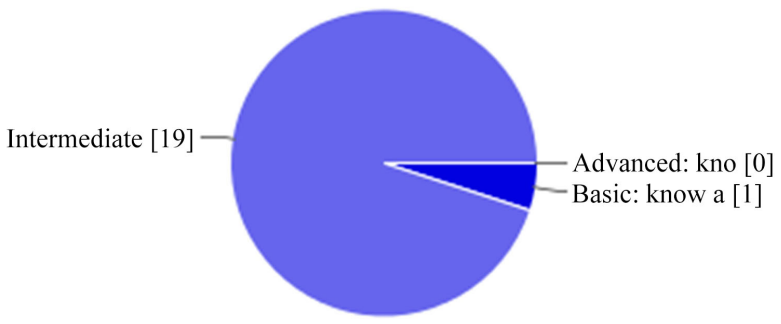

Figure 7. Please choose your present level of language ability in Maritime Terminology.

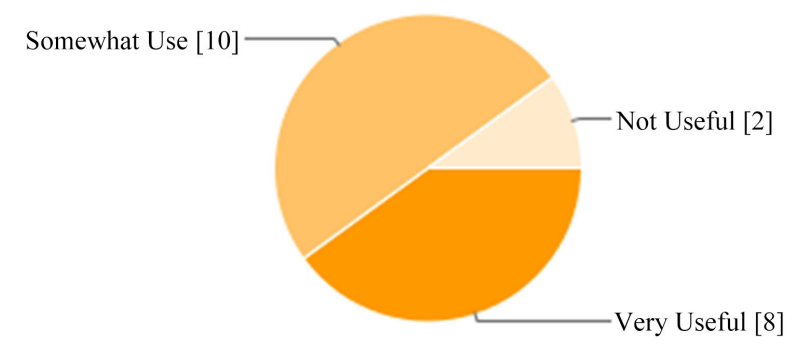

\begin{tabular}{ccc}
\hline Comment & No of responses & Percentage \% \\
\hline Very Useful & 8 & $40 \%$ \\
Useful & 10 & $50 \%$ \\
Not Useful & 2 & $10 \%$ \\
\hline
\end{tabular}

Figure 8. How useful was the course? 
Concerning maritime English, Figure 9 shows that the largest percentage of learners (45\%) admitted that there were a number of parameters that affected their learning. They learned maritime English terminology in the Marine Academies where they studied, in the field while working in vessels as well by studying engine operation manuals.

Figure 10 and Figure 11 indicated results as far as textbooks are concerned. Sixty five per cent $(65 \%)$ of learners consider the textbook they studied at the Marine Academy as useful while a similar percentage $(60 \%)$ considers the current textbook to be useful as well.

In the question to where they would attribute their current English knowledge, Figure 12 shows that eighty five per cent (85\%) of learners admitted that it was their job that dictated the need to learn the English language.

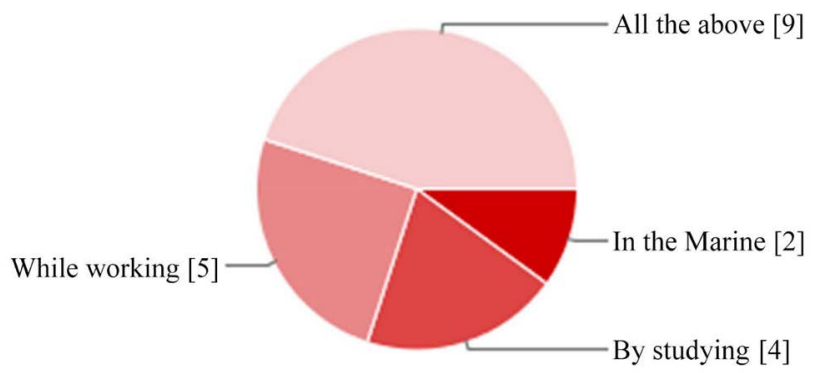

\begin{tabular}{ccc}
\hline Comment & No of responses & Percentage \% \\
\hline In the Marine Academy where you received your initial training & 2 & $10 \%$ \\
By studying engine operation and maintenance manuals & 4 & $20 \%$ \\
While working in vessels/ in the field & 5 & $25 \%$ \\
All the above & 9 & $45 \%$ \\
\hline
\end{tabular}

Figure 9. How did you learn Maritime English terminology?

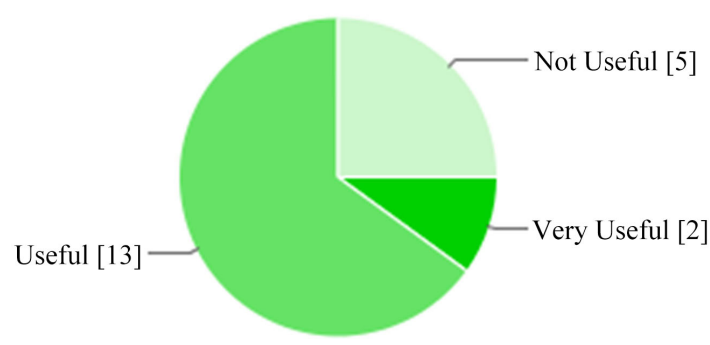

\begin{tabular}{ccc}
\hline Comment & No of responses & Percentage \% \\
\hline Very Useful & 2 & $10 \%$ \\
Useful & 13 & $65 \%$ \\
Not Useful & 5 & $25 \%$ \\
\hline
\end{tabular}

Figure 10. How useful were the textbooks you studied at the Marine Academy ("Maritime English"). 


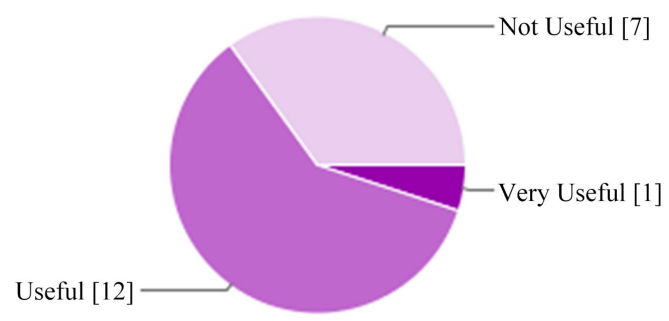

\begin{tabular}{ccc}
\hline Comment & No of responses & Percentage \% \\
\hline Very Useful & 1 & $5 \%$ \\
Useful & 12 & $60 \%$ \\
Not Useful & 7 & $35 \%$ \\
\hline
\end{tabular}

Figure 11. How useful is your current English textbook ("English for Marine Engineers (B Class)"?

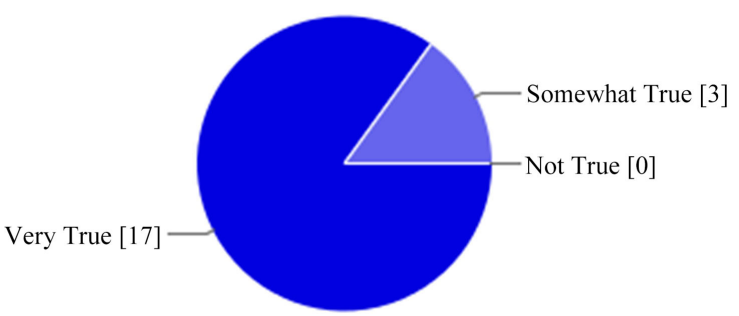

\begin{tabular}{ccc}
\hline Comment & No of responses & Percentage \% \\
\hline Very Useful & 17 & $85 \%$ \\
Useful & 3 & $15 \%$ \\
Not Useful & 0 & $0 \%$ \\
\hline
\end{tabular}

Figure 12. I need English for my job.

For further learner responses see Appendix II.

Focusing on what learners want and feel that they need to do in order to improve their English, learners seem to be once more interested in their occupation and, as shown in Figure 13, seventy five percent (75\%) believe that they can improve their English by studying engine operation and maintenance manuals.

Translation is a teaching method that learners feel that can help them in their knowledge of technical terminology. Though it is a teaching method of the past, it seems to be helpful in ESP contexts. According to Figure 14, forty per cent $(40 \%)$ of learners consider doing translation exercises useful.

Finally, concerning class activities, 35\% of learners prefer doing group work exercises (Figure 15), 25\% like pair work more (Figure 16) while 15\% prefer whole class activities (Figure 17).

For further results on what learners want and feel that they need to do in order to improve their English, see Appendix II. 


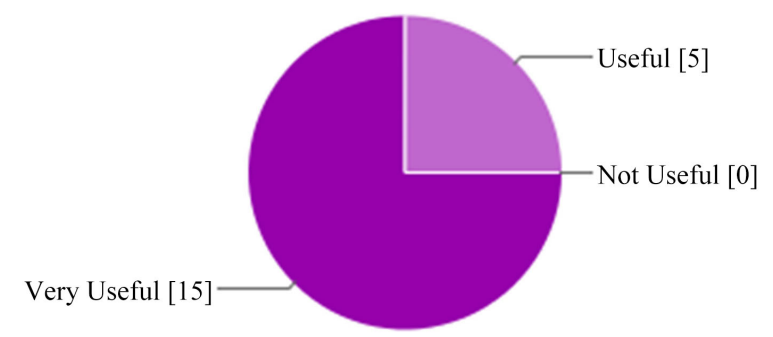

\begin{tabular}{ccc}
\hline Comment & No of responses & Percentage \% \\
\hline Very Useful & 15 & $75 \%$ \\
Useful & 5 & $25 \%$ \\
Not Useful & 0 & $0 \%$ \\
\hline
\end{tabular}

Figure 13. Studying engine operation and maintenance manuals.

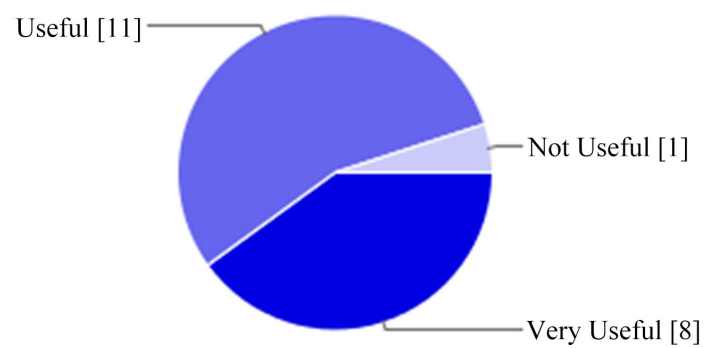

\begin{tabular}{ccc}
\hline & No of responses & Percentage \% \\
\hline Very Useful & 8 & $40 \%$ \\
Useful & 11 & $55 \%$ \\
Not Useful & 1 & $5 \%$ \\
\hline
\end{tabular}

Figure 14. Doing translation exercises.

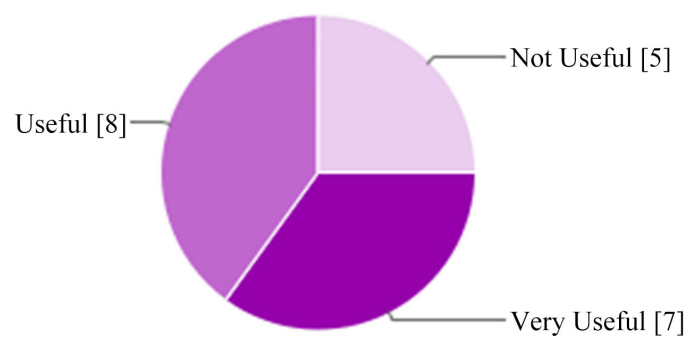

\begin{tabular}{ccc}
\hline Comment & No of responses & Percentage \% \\
\hline Very Useful & 7 & $35 \%$ \\
Useful & 8 & $40 \%$ \\
Not Useful & 5 & $25 \%$ \\
\hline
\end{tabular}

Figure 15. Doing group-work exercises. 


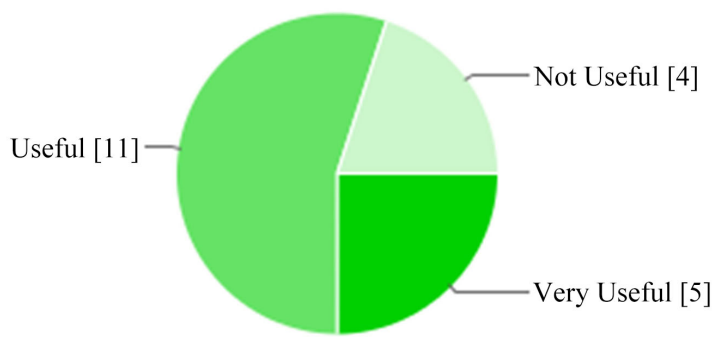

\begin{tabular}{ccc}
\hline Comment & No of responses & Percentage \% \\
\hline Very Useful & 5 & $25 \%$ \\
Useful & 1 & $55 \%$ \\
Not Useful & 4 & $20 \%$ \\
\hline
\end{tabular}

Figure 16. Doing pair-work exercises.

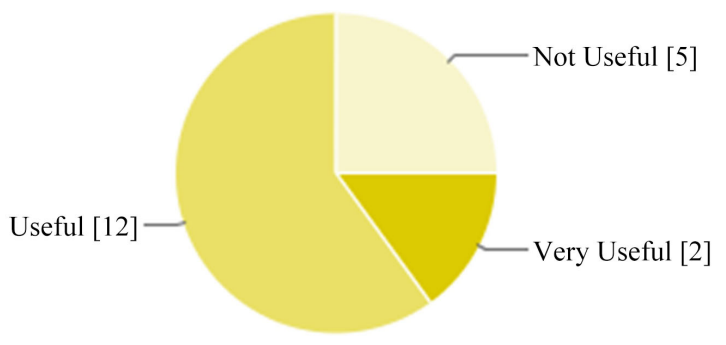

\begin{tabular}{ccc}
\hline Comment & No of responses & Percentage \% \\
\hline Very Useful & 3 & $15 \%$ \\
Useful & 12 & $60 \%$ \\
Not Useful & 5 & $25 \%$
\end{tabular}

Figure 17. Doing whole-class exercises.

\section{Discussion of Results}

After analyzing the questionnaires, it is evident that learners prefer to learn English that will be useful to them in their work. They feel that they need to be able to read engine operation manuals and written material needed for their work in vessel engine rooms. This finding is in accord with the view that learners of English are motivated by "expectancy-value," "goal-directed" and "self-determination" theories (Liuoliene \& Metiuniene, 2006). This means that they have a particular purpose in learning and they expect certain measurable results that will have direct application on their work.

An additional finding is that learners prefer group work activities. This is expected since they are adults. Jarvis, comments that adult trainers have found that group work tasks are more effective in developing professional ESP skills (Jarvis, 1983: p. 45). 
Concerning textbooks, learners find both the textbook series they studied at the Marine Academy and their current textbook useful. Still, there could be modifications made to the teaching materials like the addition of more group tasks or more vocabulary or even translation exercises.

\section{Conclusion}

This paper has aimed to investigate maritime learner needs through the use of a questionnaire. A number of interesting results were extracted which could help the teacher in the further design of her teaching material and enhancement of the class syllabus.

\section{Conflicts of Interest}

The author declares no conflicts of interest regarding the publication of this paper.

\section{References}

Ayakli, C., Karavas, K., Manolopoulou-Sergi, E., \& Spinthourakis, J. A. (2004). Course Design and Evaluation: Evaluation, Innovation and Implementation (Vol. 1). Patras: Hellenic Open University.

Beetham, H., \& Sharpe, R. (2013). An Introduction to Rethinking Pedagogy. In H. Beetham, \& R. Sharpe (Eds.), Designing for 21st Century Learning (2nd ed., pp. 3-10). New York: Routledge.

Bogdan, R. C., \& Biklen, S. K. (1998). Qualitative Research in Education. An Introduction to Theory and Methods (3rd ed.). Needham Heights: Allyn \& Bacon, a Viacom Company.

BouJaoude, S. (2000). Conceptions of Science Teaching Revealed by Metaphors and by Answers to Open-Ended Questions. Journal of Science Teacher Education, 11, 173-186. https://doi.org/10.1023/A:1009477010693

Brindley, G. (1986). The Second Language Curriculum: The Role of Needs Analysis in Adult ESL Programme Design. Cambridge: Cambridge University Press.

Herndon, J. N. (1987). Learner Interests, Achievement, and Continuing Motivation in Instruction. Journal of Instructional Development, 10, 11-12. https://doi.org/10.1007/BF02905781

Jarvis, J. (1983). Two Core Skills for ESP Teachers. The ESP Journal, 2, 45-48. https://doi.org/10.1016/0272-2380(83)90012-4

Liuoliene, A., \& Metiuniene, R. (2006). Second Language Learning Motivation. Santalka. Filologija, Edukologija, 14, 93-98. https://www.ceeol.com/search/article-detail?id=248561

Long, M. H. (2005). Second Language Needs Analysis. Cambridge: Cambridge University Press. https://doi.org/10.1017/CBO9780511667299

Richards, J. K. (2012). Curriculum Development in Language Teaching. New York: Cambridge University Press.

Tudor, I. (1996). Learner-Centredness as Language Education. Cambridge: Cambridge University Press.

West, R. (1994). Needs Analysis in Language Teaching. Cambridge Journals: Language 
Teaching, 27, 1-19. https://doi.org/10.1017/S0261444800007527

Wlodkowski, R. J. (2011). Enhancing Learner Motivation. San Francisco, CA: John Wiley \& Sons Inc. 


\section{Appendix I}

\section{Questionnaire}

Questionnaire for the needs analysis of learners of maritime English. Learners are adult marine engineers who learn both General English as a means of communication with fellow foreign crew and English for Specific Purposes used in everyday maritime engineering.

Part $A$

Very Useful Useful Not Useful

A1 Do you think that English is a useful course?

A2 Read the following situations and mark

how useful English is in each of them

1. Communicating with foreign crew

on board

2. Collaborating with foreign crew on

board

3. Communicating with foreign people

ashore

4. Familiarization with foreign cultures

5. Reading engine operation manuals

6. Ordering spare parts and supplies

7. Composing damage reports to the

employer shipping company

8. Communicating with specialized

engineers who come on board in cases

where engine operation requires

specialized service

9. Looking for employment in shipping

companies worldwide

10. Continuing your studies (maritime

or general) abroad

\section{Part B}

From the list above please choose four that are the most important for you. Write their numbers below

Part $C$

If you already speak some English, please circle your present level of language 
ability in English

General English Knowledge

C1 Basic: know a few common words and expressions; able to participate in short conversations in a few predictable topics; little knowledge of vocabulary, grammar and idioms; pronunciation heavily influenced by mother tongue

C2 Intermediate: can speak comfortably in familiar situations and topics; little difficulty with vocabulary, idioms, grammar and pronunciation

C3 Advanced: able to communicate fluently and naturally on most topics; very little difficulty with vocabulary, idioms, grammar and pronunciation

Maritime Terminology English Knowledge

C4 Basic: know a few words commonly used in the engine room

C5 Intermediate: know more words that the ones that are commonly used in the engine room

C6 Advanced: know a wide range of specialized maritime terminology

C7 If you attended a formal course in learning English as a foreign language, please indicate the length and frequency of the course (e.g. 6 years, 4 hours per week)

C8 How useful was the course?

Very Useful

Somewhat Useful

Not Useful

Why?

C9 How did you learn maritime English terminology?
A In the Marine Academy where you received your initial training
B By studying engine operation and maintenance manuals
C While working in vessels/ in the field
D All the above

C10 How useful were the English courses offered at the Marine Academy where you received your initial training?

\footnotetext{
Very Useful

Useful

Not Useful
}

C11 How useful were the textbooks you studied at the Marine Academy (“Maritime English")? 
Very Useful

Useful

Not Useful

C12 How useful is your current English textbook ("English for Marine Engineers (B Class)"?

Very Useful

Useful

Not Useful

C13 To what would you attribute your present level of ability in English?

\begin{tabular}{|c|c|c|c|c|}
\hline & & Very True & Somewhat True & Not True \\
\hline 1. & I attended a useful course & $\square$ & $\square$ & $\square$ \\
\hline \multirow[t]{3}{*}{2.} & Studying English at the Marine & $\square$ & $\square$ & $\square$ \\
\hline & Academy improved my & & & \\
\hline & language level & & & \\
\hline 3. & I studied with a private tutor & $\square$ & $\square$ & $\square$ \\
\hline \multirow[t]{4}{*}{4.} & I visited many English & $\square$ & $\square$ & $\square$ \\
\hline & speaking countries or & & & \\
\hline & countries where I used English & & & \\
\hline & as a communication language & & & \\
\hline \multirow[t]{2}{*}{5.} & I make every effort to use & $\square$ & $\square$ & $\square$ \\
\hline & English & & & \\
\hline 6. & I enjoy studying English & $\square$ & $\square$ & $\square$ \\
\hline 7. & I need English for my job & $\square$ & $\square$ & $\square$ \\
\hline 8. & I am a good language learner & $\square$ & $\square$ & $\square$ \\
\hline \multirow[t]{3}{*}{9.} & I get a lot of help from fellow & $\square$ & $\square$ & $\square$ \\
\hline & workers and English speaking & & & \\
\hline & friends & & & \\
\hline \multirow[t]{2}{*}{10.} & $\begin{array}{l}\text { I expose myself to English a lot by } \\
\text { watching films or by }\end{array}$ & $\square$ & $\square$ & $\square$ \\
\hline & listening to songs in English & & & \\
\hline
\end{tabular}

C14 What activities or experiences were most useful in your study of English? Please elaborate

Part $D$

If you have studied English in the past and you have stopped, please check the appropriate boxes below 


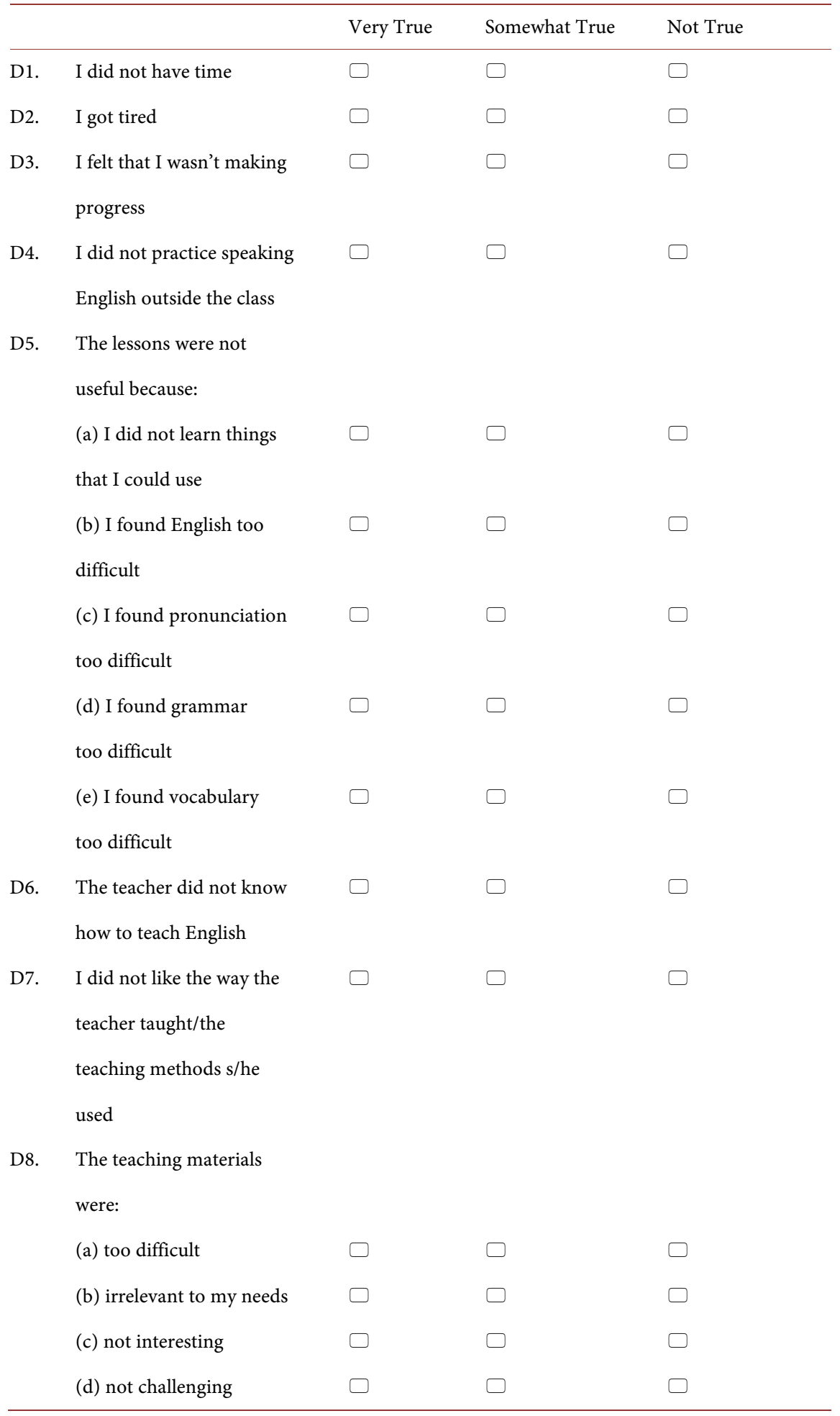

\section{Other:}

Part E

Have you ever done the following activities in studying English? How useful were they? 


\begin{tabular}{|c|c|c|c|c|}
\hline & & Very Useful & Useful & Not Useful \\
\hline E1. & $\begin{array}{l}\text { Practicing dialogues from } \\
\text { a book }\end{array}$ & $\square$ & $\square$ & $\square$ \\
\hline E2. & $\begin{array}{l}\text { Practicing drills on tones, } \\
\text { sounds and grammatical } \\
\text { patterns }\end{array}$ & $\square$ & $\square$ & $\square$ \\
\hline E3. & $\begin{array}{l}\text { Free conversation with } \\
\text { native speakers }\end{array}$ & $\square$ & $\square$ & $\square$ \\
\hline E4. & $\begin{array}{l}\text { Free conversation with } \\
\text { other learners of English }\end{array}$ & $\square$ & $\square$ & $\square$ \\
\hline E5. & $\begin{array}{l}\text { Studying engine operation } \\
\text { and maintenance manuals }\end{array}$ & $\square$ & $\square$ & $\square$ \\
\hline E6. & Translating engine manuals & $\square$ & $\square$ & $\square$ \\
\hline E7. & $\begin{array}{l}\text { Memorizing bilingual } \\
\text { vocabulary lists }\end{array}$ & $\square$ & $\square$ & $\square$ \\
\hline E8. & $\begin{array}{l}\text { Studying differences between } \\
\text { English and Greek }\end{array}$ & $\square$ & $\square$ & $\square$ \\
\hline E9. & Doing whole-class exercises & $\square$ & $\square$ & $\square$ \\
\hline E10. & Doing pair-work exercises & $\square$ & $\square$ & $\square$ \\
\hline E11. & Doing group-work exercises & $\square$ & $\square$ & $\square$ \\
\hline E12. & Doing translation exercises & $\square$ & $\square$ & $\square$ \\
\hline E13. & $\begin{array}{l}\text { Watching TV in English at } \\
\text { home }\end{array}$ & $\square$ & $\square$ & $\square$ \\
\hline E14. & $\begin{array}{l}\text { Watching films or listening } \\
\text { to songs in English }\end{array}$ & $\square$ & $\square$ & $\square$ \\
\hline E15. & $\begin{array}{l}\text { Watching or listening to } \\
\text { people speaking English }\end{array}$ & $\square$ & $\square$ & $\square$ \\
\hline E16. & Talking to friends in English & $\square$ & $\square$ & $\square$ \\
\hline E17. & $\begin{array}{l}\text { Trying to use English } \\
\text { whenever I am given } \\
\text { the opportunity }\end{array}$ & $\square$ & $\square$ & $\square$ \\
\hline E18. & $\begin{array}{l}\text { Putting myself in situations } \\
\text { in which I will be forced } \\
\text { to speak or use English } \\
\text { like choosing the English }\end{array}$ & $\square$ & $\square$ & $\square$ \\
\hline
\end{tabular}




\section{Continued}

speaking menu on an

electronic or Internet

application or on a help

desk menu

E19. Trying to find ways to make

myself understood even if

I make many mistakes

E20. Speaking good English

without making mistakes

in grammar/syntax or pronunciation

E21. Studying English as a class

member/ student

E22. Studying with a private tutor

Other:

\section{Part F}

In class or with a tutor, I would like my teacher to:

No A little Good Best

F1. Explain new grammar/syntax/vocabulary points before practicing them

F2. Practice new grammar/syntax/vocabulary points before explaining them

F3. Correct any mistakes I make immediately

F4. Correct any mistakes I make after some time

F5. Correct any mistakes I make in front of others

F6. Correct any mistakes I make discretely to me

F7. Correct my mistakes of pronunciation

F8. Correct my mistakes of vocabulary

F9. Correct my mistakes of grammar/syntax

F10. Use English only

F11. Use both English and Greek

Part $G$

How do you feel about English as a language? 


\begin{tabular}{|c|c|c|c|c|}
\hline & & Very True & True & Not True \\
\hline G1. & $\begin{array}{l}\text { English is an easy-to-learn } \\
\text { language }\end{array}$ & $\square$ & $\square$ & $\square$ \\
\hline G2. & $\begin{array}{l}\text { English is a difficult-to-learn } \\
\text { language }\end{array}$ & $\square$ & $\square$ & $\square$ \\
\hline G3. & $\begin{array}{l}\text { English has difficult grammar/ } \\
\text { syntax }\end{array}$ & $\square$ & $\square$ & $\square$ \\
\hline G4. & $\begin{array}{l}\text { English has difficult } \\
\text { vocabulary }\end{array}$ & $\square$ & $\square$ & $\square$ \\
\hline G5. & $\begin{array}{l}\text { English has difficult } \\
\text { pronunciation }\end{array}$ & $\square$ & $\square$ & $\square$ \\
\hline G6. & $\begin{array}{l}\text { English is made up of many } \\
\text { idioms }\end{array}$ & $\square$ & $\square$ & $\square$ \\
\hline G7. & $\begin{array}{l}\text { English is made up of many } \\
\text { colloquial expressions }\end{array}$ & $\square$ & $\square$ & $\square$ \\
\hline G8. & $\begin{array}{l}\text { English is a language that } \\
\text { can express technical } \\
\text { meanings economically and } \\
\text { with precision }\end{array}$ & $\square$ & $\square$ & $\square$ \\
\hline G9. & $\begin{array}{l}\text { English is a commercially } \\
\text { used language }\end{array}$ & $\square$ & $\square$ & $\square$ \\
\hline G10. & $\begin{array}{l}\text { English is a language where } \\
\text { pronunciation is very } \\
\text { important }\end{array}$ & $\square$ & $\square$ & $\square$ \\
\hline G11. & $\begin{array}{l}\text { English is a beautiful } \\
\text { sounding language }\end{array}$ & $\square$ & $\square$ & $\square$ \\
\hline G12. & English is a polite language & $\square$ & $\square$ & $\square$ \\
\hline G13. & $\begin{array}{l}\text { English is a harsh sounding } \\
\text { language }\end{array}$ & $\square$ & $\square$ & $\square$ \\
\hline G15. & $\begin{array}{l}\text { English is a vulgar sounding } \\
\text { language }\end{array}$ & $\square$ & $\square$ & $\square$ \\
\hline G16. & $\begin{array}{l}\text { English is a soft sounding } \\
\text { language }\end{array}$ & $\square$ & $\square$ & $\square$ \\
\hline
\end{tabular}

\section{Other:}

Adapted by Richards (2012). Curriculum Development in Language Teaching. New York: Cambridge University Press, pages 73-79. 


\section{Appendix II}

\section{Further learner responses}

Question: Why is English useful to you?

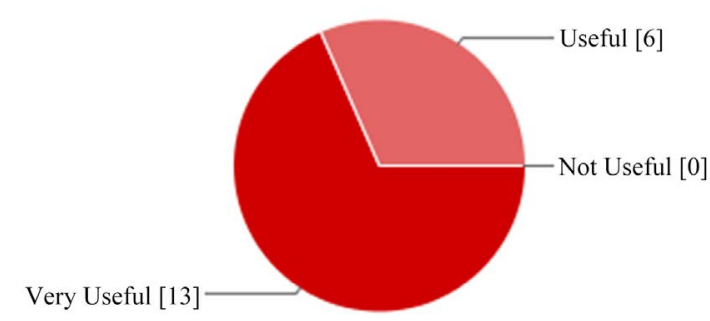

\begin{tabular}{ccc}
\hline Comment & No of responses & Percentage \% \\
\hline Very Useful & 13 & $65 \%$ \\
Useful & 6 & $30 \%$ \\
Not Useful & 0 & $0 \%$ \\
\hline
\end{tabular}

Figure A1. Communicating with specialized engineers who come on board in cases where engine operation requires specialized service.

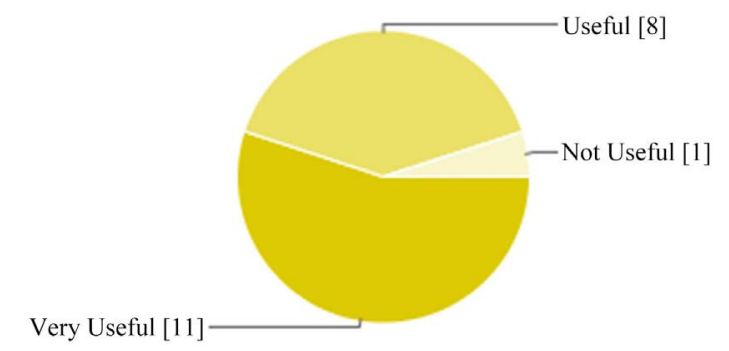

\begin{tabular}{ccc}
\hline Comment & No of responses & Percentage \% \\
\hline Very Useful & 11 & $55 \%$ \\
Useful & 8 & $40 \%$ \\
Not Useful & 1 & $5 \%$ \\
\hline
\end{tabular}

Figure A2. Looking for employment in shipping companies worldwide.

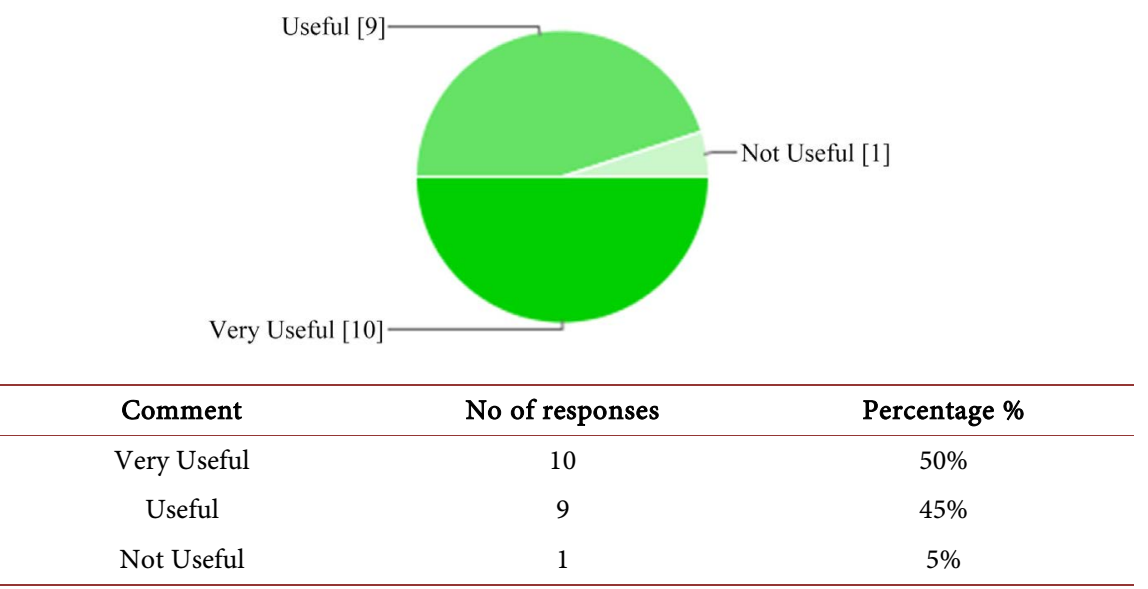

Figure A3. Continuing your studies (maritime or general) abroad. 
Question: To what would you attribute your present level of ability in English?

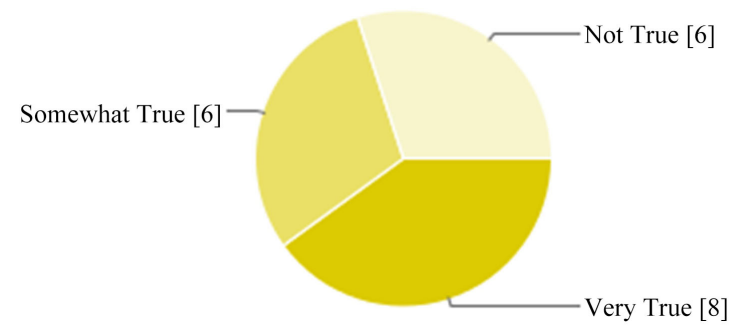

\begin{tabular}{ccc}
\hline Comment & No of responses & Percentage \% \\
\hline Very Useful & 8 & $40 \%$ \\
Useful & 6 & $30 \%$ \\
Not Useful & 6 & $30 \%$ \\
\hline
\end{tabular}

Figure A4. I visited many English speaking countries or countries where I used English as a communication language.

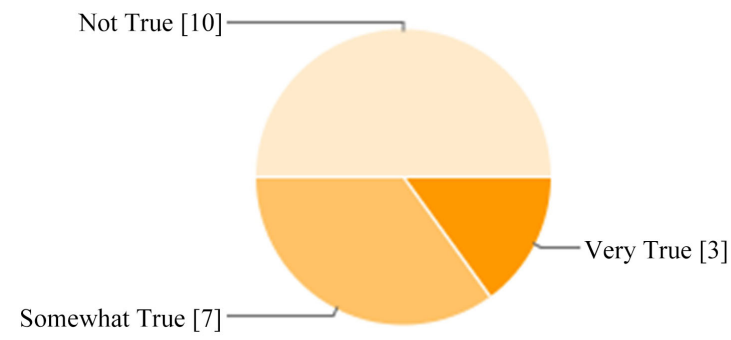

\begin{tabular}{ccc}
\hline Comment & No of responses & Percentage \% \\
\hline Very Useful & 3 & $15 \%$ \\
Useful & 7 & $35 \%$ \\
Not Useful & 10 & $50 \%$
\end{tabular}

Figure A5. Studying English at the Marine Academy improved my language level.

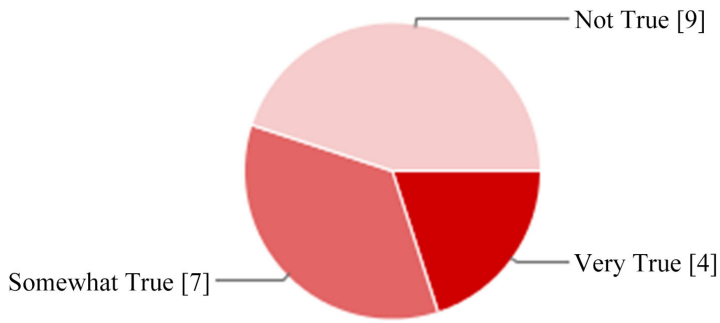

\begin{tabular}{ccc}
\hline Comment & No of responses & Percentage \% \\
\hline Very Useful & 4 & $20 \%$ \\
Useful & 7 & $35 \%$ \\
Not Useful & 9 & $45 \%$ \\
\hline
\end{tabular}

Figure A6. I studied with a private tutor. 


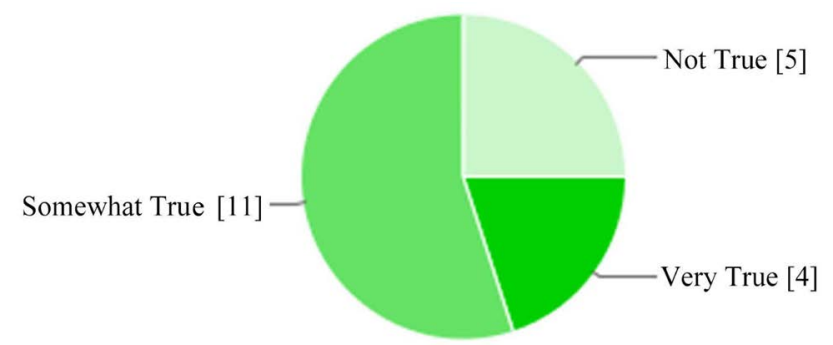

\begin{tabular}{ccc}
\hline Comment & No of responses & Percentage \% \\
\hline Very Useful & 4 & $20 \%$ \\
Useful & 11 & $55 \%$ \\
Not Useful & 5 & $25 \%$ \\
\hline
\end{tabular}

Figure A7. I make every effort to use English.

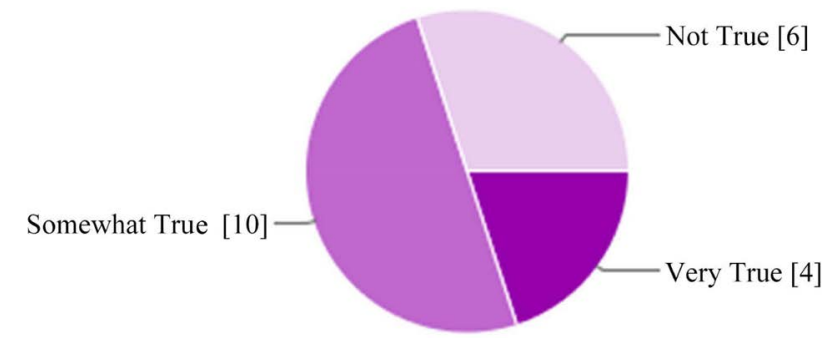

\begin{tabular}{ccc}
\hline Comment & No of responses & Percentage \% \\
\hline Very Useful & 4 & $20 \%$ \\
Useful & 10 & $50 \%$ \\
Not Useful & 6 & $35 \%$ \\
\hline
\end{tabular}

Figure A8. I enjoy studying English.

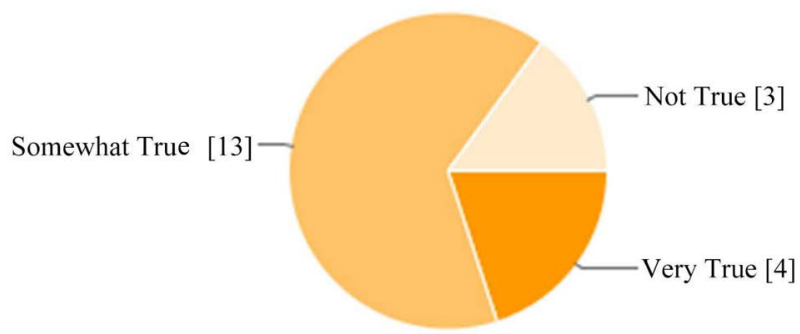

\begin{tabular}{ccc}
\hline Comment & No of responses & Percentage \% \\
\hline Very Useful & 4 & $20 \%$ \\
Useful & 13 & $65 \%$ \\
Not Useful & 3 & $15 \%$ \\
\hline
\end{tabular}

Figure A9. I am a good language learner. 


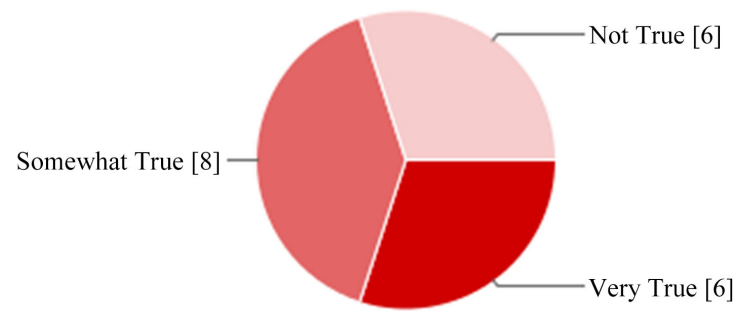

\begin{tabular}{ccc}
\hline Comment & No of responses & Percentage \% \\
\hline Very Useful & 6 & $30 \%$ \\
Useful & 8 & $40 \%$ \\
Not Useful & 6 & $30 \%$ \\
\hline
\end{tabular}

Figure A10. I get a lot of help from fellow workers and English speaking friends.

\section{Question:-What activities could someone do to improve their English?}

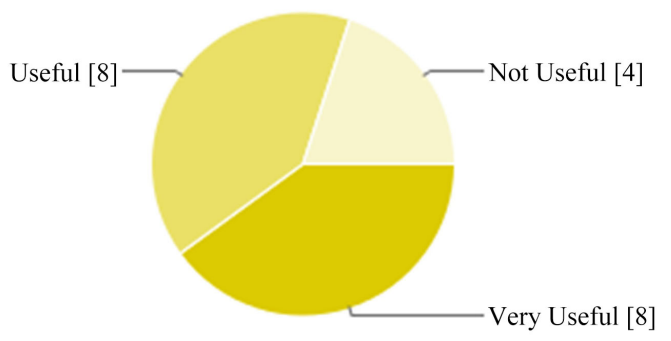

\begin{tabular}{ccc}
\hline Comment & No of responses & Percentage \% \\
\hline Very Useful & 8 & $40 \%$ \\
Useful & 8 & $40 \%$ \\
Not Useful & 4 & $20 \%$ \\
\hline
\end{tabular}

Figure A11. Watching or listening to people speaking English.

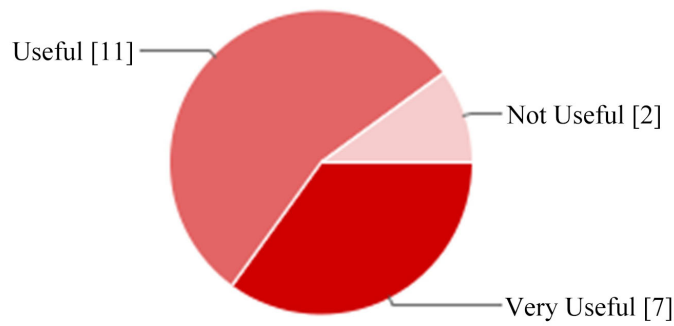

\begin{tabular}{ccc}
\hline Comment & No of responses & Percentage \% \\
\hline Very Useful & 7 & $35 \%$ \\
Useful & 11 & $55 \%$ \\
Not Useful & 2 & $10 \%$ \\
\hline
\end{tabular}

Figure A12. Watching films or listening to songs in English. 


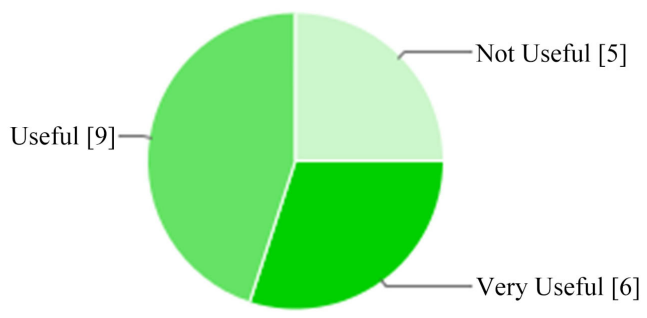

\begin{tabular}{ccc}
\hline Comment & No of responses & Percentage \% \\
\hline Very Useful & 6 & $30 \%$ \\
Useful & 9 & $45 \%$ \\
Not Useful & 5 & $25 \%$ \\
\hline
\end{tabular}

Figure A13. Talking to friends in English.

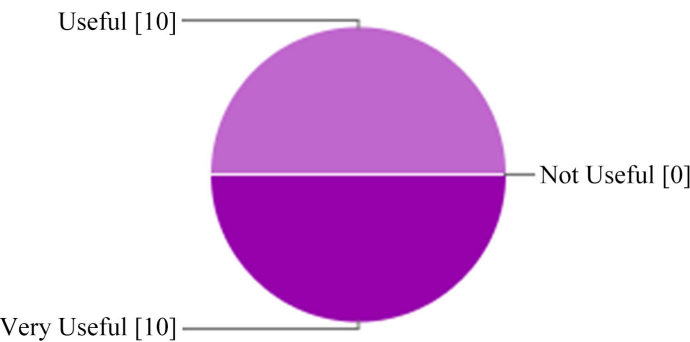

\begin{tabular}{ccc}
\hline Comment & No of responses & Percentage \% \\
\hline Very Useful & 10 & $50 \%$ \\
Useful & 10 & $50 \%$ \\
Not Useful & 0 & $50 \%$ \\
\hline
\end{tabular}

Figure A14. Trying to use English whenever I am given the opportunity.

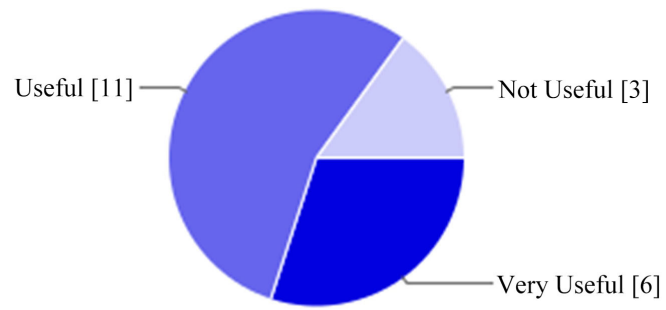

\begin{tabular}{ccc}
\hline Comment & No of responses & Percentage \% \\
\hline Very Useful & 6 & $30 \%$ \\
Useful & 11 & $55 \%$ \\
Not Useful & 3 & $15 \%$ \\
\hline
\end{tabular}

Figure A15. Putting myself in situations in which I will be forced to speak or use English like choosing the English speaking menu on an electronic or Internet application or on a help desk menu. 


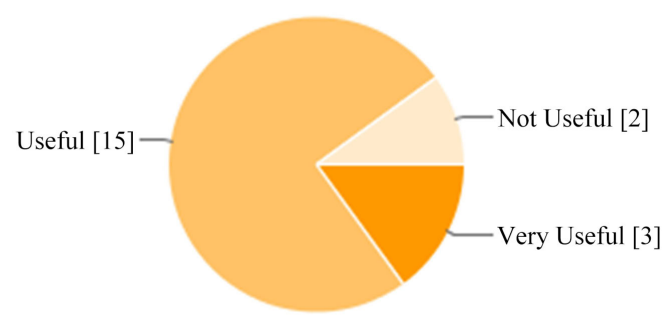

\begin{tabular}{ccc}
\hline Comment & No of responses & Percentage \% \\
\hline Very Useful & 3 & $15 \%$ \\
Useful & 15 & $75 \%$ \\
Not Useful & 2 & $10 \%$ \\
\hline
\end{tabular}

Figure A16. Trying to find ways to make myself understood even if I make many mistakes.

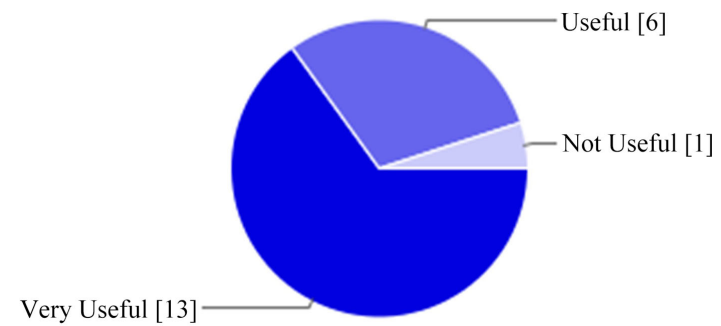

\begin{tabular}{ccc}
\hline Comment & No of responses & Percentage \% \\
\hline Very Useful & 13 & $65 \%$ \\
Useful & 6 & $30 \%$ \\
Not Useful & 1 & $5 \%$
\end{tabular}

Figure A17. Translating engine manuals.

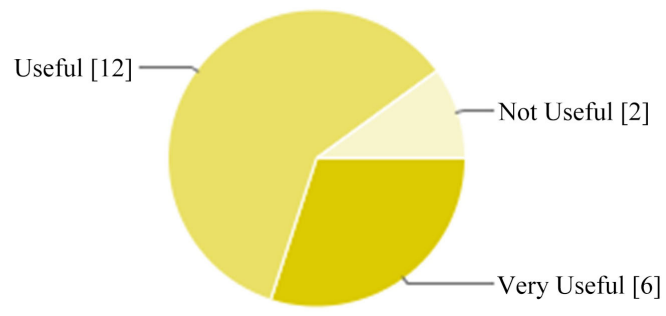

\begin{tabular}{ccc}
\hline Comment & No of responses & Percentage \% \\
\hline Very Useful & 6 & $30 \%$ \\
Useful & 12 & $60 \%$ \\
Not Useful & 2 & $10 \%$ \\
\hline
\end{tabular}

Figure A18. Free conversation with native speakers. 


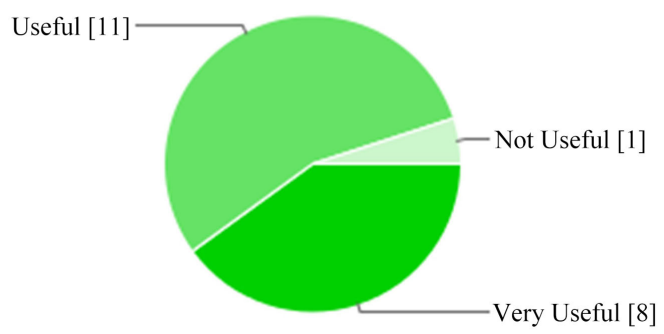

\begin{tabular}{ccc}
\hline Comment & No of responses & Percentage \% \\
\hline Very Useful & 8 & $40 \%$ \\
Useful & 11 & $55 \%$ \\
Not Useful & 1 & $5 \%$ \\
\hline
\end{tabular}

Figure A19. Free conversation with other learners of English. 